Strange, R. E. \& Dark, F. A. (1957). J. gen. Microbiol. 16, 236-249

\title{
A Cell-wall Lytic Enzyme Associated with Spores of Bacillus Species
}

\author{
By R. E. STRANGE AND F. A. DARK \\ Microbiological Research Establishment, Porton, Wiltshire
}

SUMMARY: Aqueous extracts of disintegrated spores of Bacillus cereus and nonvirulent $B$. anthracis contained an enzyme which produced visible lysis of the isolated cell walls of vegetative $B$. cereus. Optimum activity occurred at pH 7-8 in the presence of cobalt or manganese ions (10 p.p.m.) at $58^{\circ}$. Activity was destroyed during heating at $100^{\circ}$ for $15 \mathrm{~min}$. The lytic preparation released non-dialysable components containing $\alpha \epsilon$-diaminopimelic acid (DAP), glutamic acid, alanine, amino sugars and glucose. Although lysis was less obvious, the enzyme preparation released similar material from cell walls of other Bacillus species, spore coats of B. megaterium and coats of autoclaved B. cereus spores. Extracts of freshly harvested $B$. cereus spores were more active than those from spores which had been stored for several weeks at $2^{\circ}$. Extracts from disintegrated spores of $B$. megaterium had no enzymic activity; the enzyme system was associated with the insoluble spore coat fraction. The action of the enzyme differed from that of lysozyme or glucosaminidase; the reaction products did not give a signifieant reaction for $N$-acetylhexosamine and visible lysis proceeded more rapidly with cell walls of $B$. cereus than with $B$. megaterium. Possible functions of the enzyme may be to release 'spore peptide' from the spore coat during germination and to lyse the sporangium and free the spore during sporulation.

Spore germination in Bacillus species is accompanied by the excretion of calcium dipicolinate, amino acids and a non-dialysable peptide containing DAP, glutamic acid, alanine and amino sugars (Powell \& Strange, 1953; Powell, 1953; Strange \& Powell, 1954; Strange \& Dark, 1956a). It has been suggested (Strange \& Dark, 1956b) that the peptide is a constituent of the spore coat from which it is freed during germination or mechanical disruption, by the action of an enzyme present in the spore. Strange \& Dark (1956b) found that spore-coat preparations of Bacillus megaterium still contained considerable amounts of peptide which was slowly and spontaneously released into water and buffer solutions. Similar preparations from $B$. cereus and B. subtilis contained only small amounts of peptide. Evidence for the build up of an intracellular enzyme system in sporulating $B$. cereus has recently been found by Powell \& Strange (1956). The hexosamine and DAP content of extracts of $\boldsymbol{B}$. cereus increased as sporulation proceeded; so also did their ability to split off from vegetative cell walls a complex containing hexosamine and DAP.

The present paper describes a partial purification of the enzyme system, some of its properties, and the products of its activity. A brief account of some of this work has already been presented (Strange \& Dark, 1956c). 


\section{METHODS}

Organisms. Vegetative organisms and spores of a laboratory strain of Bacillus cereus were grown in potato extract medium (Robinow, 1951) enriched with 1/10th vol. of casein hydrolysate + yeast extract (Gladstone \& Fildes, 1940) as described by Powell \& Strange (1956). Vegetative cells of laboratory strains of $B$. megaterium and $B$. subtilis were grown in tryptic meat broth. Thompson bottles containing $200 \mathrm{ml}$. of medium were inoculated with $1 \mathrm{ml}$. spore suspension (c. $10^{7}$ spores) and shaken for $16-18 \mathrm{hr}$. at $37^{\circ}$. The vegetative organisms were washed twice with $0.9 \%(\mathrm{w} / \mathrm{v})$ saline and twice with distilled water by centrifugation at $0^{\circ}$.

Spores of Bacillus cereus were washed 5 times by centrifugation in saline and once in water. They were resuspended in water and stored for 4-7 days at $2^{\circ}$. After one more washing with water, stained films of the suspension were made. Vegetative debris was usually absent at this stage but if this persisted, the suspensions were stored for a further period at $2^{\circ}$ and rewashed with water. Spores of an avirulent strain of $B$. anthracis (Sterne, 1937) were obtained by cultivation in shaken Thompson bottles containing $200 \mathrm{ml}$. of casein hydrolysate + yeast extract medium (Gladstone \& Fildes, 1940) for $44 \mathrm{hr}$. at $37^{\circ}$. Clean spore suspensions of this organism were obtained as described for $B$. cereus.

Preparation of vegetative cell walls. Suspensions of freshly harvested vegetative organisms (10 mg. dry wt./ml.) were disintegrated in the Mickle (1948) tissue disintegrator with glass beads (Ballotini, size 12, from Chance Bros. Ltd.) and cell walls were obtained essentially as described by Salton \& Horne (1951). The isolated cell walls were washed twice with saline and twice with distilled water and freeze-dried. Microscopic examinations were made of wet films of the preparations in dilute methylene blue. A preparation from Bacillus cereus was also examined under a Siemen's electron microscope with a magnification $\times 10,000$ by Mr W. F. Harris of the Chemical Defence Experimental Establishment. As far as could be judged by these methods, the preparations consisted essentially of cell walls.

\section{Preparation of crude enzyme solution from spores of Bacillus cereus and $\mathrm{B}$. anthracis}

Batches of spore suspension containing 10-25 mg. dry wt./ml. (16 hr., 100 $)$ were disintegrated in the Mickle tissue disintegrator with Ballotini, size 12, for $45 \mathrm{~min}$. at $2^{\circ}$. The suspension was centrifuged at $6,000 \mathrm{~g}$. for $20 \mathrm{~min}$. and the supernatant fluid filtered through a sterile sintered glass filter (porosity, 5/3). To obtain a solution of lytic enzyme free from spore peptide, thus avoiding a high 'blank value' in the lytic tests (see below), the filtrate was cooled to $2^{\circ}$ and treated with an equal volume of cold, McIlvaine's sodium phosphate + citric acid buffer ( $\mathrm{pH}$ 3.0). After standing at $2^{\circ}$ for $15 \mathrm{~min}$. the precipitate was centrifuged and washed with cold buffer ( $\mathrm{pH} 3 \cdot 0)$. The washed precipitate, which contained most of the lytic enzyme, was dissolved in McIlvaine's buffer $(\mathrm{pH} 7 \cdot 4)$ and the volume adjusted with buffer to $1 / 4$ that of the filtered spore 
extract. This solution contained enzyme from 40 to $100 \mathrm{mg}$. (dry wt.) of spores and its hexosamine content determined after hydrolysis with $6 \mathrm{~N}-\mathrm{HCl}$ was negligible. The buffered solution was freeze-dried and stored without loss of activity.

Determination of activity of crude enzyme preparations. Owing to the spontaneous lysis of cell-wall suspensions of vegetative Bacillus cereus (see Results) they were not satisfactory for the determination of the activity of the spore enzyme. This difficulty was avoided when cell-wall suspensions were heated at $100^{\circ}$ before addition of enzyme solution. Freeze-dried cell walls of $B$. cereus were suspended in water $(6 \mathrm{mg} . / \mathrm{ml}$.) and heated in a boiling water bath for 15 min. The suspension was centrifuged and the cell walls resuspended in water at the original concentration. A measured volume of cell-wall suspension $(0.5 \mathrm{ml}$.) was treated with enzyme solution $(0.25 \mathrm{ml}$.), water $(0.25 \mathrm{ml}$.) and one drop of toluene. The tube was sealed and incubated in parallel with control tubes containing cell walls without enzyme and enzyme without cell walls. Temperature and time of incubation varied; details are given in Results. Measurement of enzymic activity by comparison of optical density readings was not generally adopted because (1) during incubation material precipitated out from the enzyme solution, (2) cell-wall suspension often contained floccules which sedimented rapidly, (3) dilute enzyme solutions did not produce a measurable effect. Instead, hexosamine was determined in the supernatant fluid after hydrolysis with $6 \mathrm{~N}-\mathrm{HCl}$ for $2 \mathrm{hr}$. at $100^{\circ}$ as described by Powell \& Strange (1956). No hexosamine was found in the supernatant fluid from a suspension of heated $B$. cereus cell walls incubated without enzyme and the amount present in the enzyme solution itself was negligible. The hexosamine content of freeze-dried vegetative cell walls of $B$. cereus after hydrolysis with $6 \mathrm{~N}-\mathrm{HCl}$ for $2 \mathrm{hr}$. at $100^{\circ}$ was $30-35 \%$ (as glucosamine) so that the maximum amount possible in the test supernatant was $c .1 \mathrm{mg} . / \mathrm{ml}$.

Analytical methods. Amino acids and amino sugars were detected by twodimensional paper chromatography (Consden, Gordon \& Martin, 1944) after hydrolysis with $6 \mathrm{~N}-\mathrm{HCl}$ for $16 \mathrm{hr}$. at $100^{\circ}$ in a sealed tube. The substituted amino sugar (Strange \& Dark, 1956a; Strange, 1956) was separated from hexosamine by ascending paper chromatography with a mixture of tertbutanol $/ 6 \mathrm{~N}-\mathrm{HCl} / \mathrm{H}_{2} \mathrm{O}$ in the volume ratio $70: 1: 29$ as solvent, and the amino sugars were detected with ammoniacal $\mathrm{AgNO}_{3}$ (Partridge, 1948). Sugars were detected by single-dimensional paper chromatography after hydrolysis with $\mathrm{N}-\mathrm{HCl}$ for $16 \mathrm{hr}$. at $100^{\circ}$ in a sealed tube, aniline hydrogen phthalate being used as the spray reagent (Partridge, 1949). In all cases material for paper chromatography was freed from acid by evaporation in vacuo over sulphuric acid and caustic soda. Nitrogen was determined by a micro Kjeldahl-nesslerization method, phosphorus by the method of King (1932), total carbohydrate (excluding hexosamine) by the method of Sorensen \& Haugaard (1933), hexosamine by the method of Elson \& Morgan (1933) as modified by Immers \& Vasseur (1950) after hydrolysis of the material with $6 \mathrm{~N}-\mathrm{HCl}$ for $2 \mathrm{hr}$. in a sealed tube, and $N$-acetyl hexosamine by the method of Morgan \& Elson (1934). DAP was estimated by means of the Chinard (1952) reaction, a method suggested by 
Dr Elizabeth Work. A solution of hydrolysed material containing not more than $100 \mu \mathrm{g}$. DAP $/ \mathrm{ml}$. was heated with the acid ninhydrin solution for $5 \mathrm{~min}$. at $100^{\circ}$. After dilution, the optical density was measured in a Unicam quartz spectrophotometer at $430 \mathrm{~m} \mu$. and compared with standards treated similarly. None of the cell-wall components examined contained interfering amino acids. Paper electrophoresis examinations were made in the tank designed by Flynn \& De Mayo (1951) on Whatman no. 4 paper using veronal/veronal sodium buffer ( $\mathrm{pH} 8 \cdot 6)$ and a voltage of 200 . The components were detected with naphthalene black.

\section{RESULTS}

\section{Spontaneous lysis of cell-wall suspensions}

The tendency of suspensions of cell walls to lyse spontaneously increased as sporulation proceeded in the organisms from which they were obtained. Freeze-dried cell walls were prepared from Bacillus cereus grown in potato extract medium for various times. Duplicate amounts ( $3 \mathrm{mg}$.) were suspended in $0.02 \mathrm{M}$-phosphate buffer $(\mathrm{pH} 7.4 ; 1 \mathrm{ml}$.) with one drop of toluene and

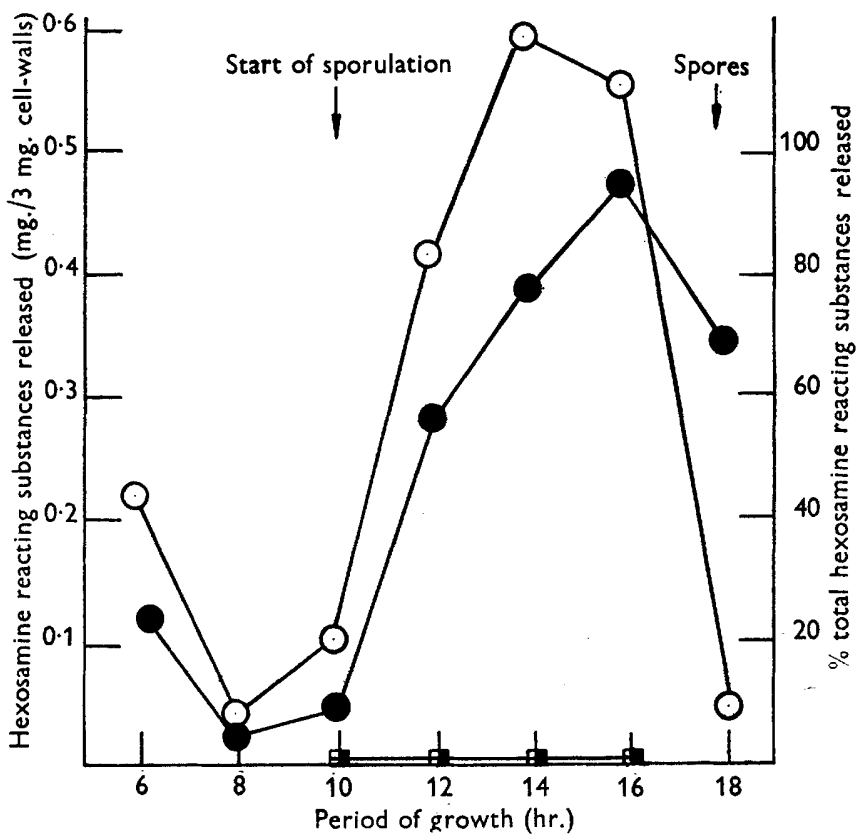

Fig. 1. Spontaneous lysis of Bacillus cereus cell walls suspended in $0.02 \mathrm{M}$-phosphate buffer (pH 7.4) for $16 \mathrm{hr}$. at $37^{\circ}$, in terms of the amount of hexosamine found in the acidhydrolysed supernatant fluid; $\mathrm{mg}$. hexosamine $/ 3 \mathrm{mg}$. cell walls $(0)$; \% total hexosamine released ( ). Release of hexosamine from cell walls heated at $100^{\circ}$ for $15 \mathrm{~min}$. (प).

incubated for $16 \mathrm{hr}$. at $37^{\circ}$. The extent of dissolution of each preparation, expressed in terms of the quantity of hexosamine found in the hydrolysed supernatant fluid, is shown in Fig. 1. In the medium used, the first signs of sporulation were evident after 10-12 hr. of incubation at $37^{\circ}$ and the process was almost complete after $18 \mathrm{hr}$. Spontaneous dissolution of walls from 
organisms harvested after 6-10 hr. growth was slight and only $100 \mu \mathrm{g}$. hexosamine was released. With walls of organisms harvested after $14 \mathrm{hr}$. growth, the degree of dissolution was considerable and $600 \mu \mathrm{g}$. hexosamine was found in the supernatant fluid. Thus in the tests of enzymic activity, substrate degradation could be decreased by selection of non-sporulating organisms; it was completely avoided by heating the preparations for $15 \mathrm{~min}$. at $100^{\circ}$ (Fig. 1). Such treatment did not affect the subsequent action of the spore enzyme.

\section{The effect of storage on the amount of extractable enzyme in Bacillus cereus spores}

It was found that a suspension of viable Bacillus cereus spores which had been stored at $2^{\circ}$ for one year provided a less active enzyme solution than was obtained from a freshly harvested spore suspension. A clean spore suspension (24 $\mathrm{mg}$. dry wt. $/ \mathrm{ml}$.) was prepared and stored at $2^{\circ}$. At intervals of 7 days, spore extracts were prepared and their enzymic activities determined (Table 1). After 7 weeks the extractable activity had fallen to $20 \%$ of that present in extracts from freshly harvested spores. For most of the experiments described in this paper, enzyme solutions were prepared from freshly harvested spores.

\section{Table 1. Decrease in extractable enzyme in Bacillus cereus spores after storage}

Buffer: 1:4 McIlvaine's (pH 7.4); substrate: 3 mg. Bacillus cereus cell walls; lytic enzyme from $24.0 \mathrm{mg}$. B. cereus spores; incubation $44 \mathrm{hr}$. at $37^{\circ}$; toluene as preservative; duplicate tests.

$\begin{array}{llllllllll}\text { Age of suspension (weeks) } & \ldots & 1 & 2 & 3 & 5 & 6 & 7 & 8 & 52\end{array}$

$\begin{array}{lllllllll}\text { Substrate hexosamine released (\%) } & 91 & 78 & 52 & 35 & 23 & 19 & 22 & 12\end{array}$

\section{Optimum $\mathrm{pH}$ for enzymic activity}

A series of precipitates obtained at $\mathrm{pH} \mathrm{3.0}$ from $10 \mathrm{ml}$. volumes of extracts of Bacillus cereus spores $(22 \cdot 6 \mathrm{mg}$. dry wt./ml.) were suspended or dissolved in $\mathbf{2 . 5} \mathrm{ml}$. volumes of McIlvaine's buffer of different $\mathrm{pH}$ values and the activity of the buffered enzyme preparations determined (Table 2). The optimum pH value for enzymic activity was between $7 \cdot 0-8 \cdot 0$ and as the $\mathrm{pH}$ value of whole spore extract was $7 \cdot 4$, this value was used in lytic tests.

Table 2. Effect of $\mathrm{pH}$ value on the activity of Bacillus cereus spore enzyme

Buffers: 1:4 McIlvaine's; substrate: $3 \mathrm{mg}$. Bacillus cereus cell walls; lytic enzyme from $23 \mathrm{mg}$. B. cereus spores; incubation: $44 \mathrm{hr}$. at $37^{\circ}$; toluene as preservative; duplicate tests.

$\begin{array}{llccccc}\text { pH value } \quad \ldots & 4 \cdot 25 & 5 \cdot 3 & 6 \cdot 2 & 7 \cdot 1 & 7 \cdot 7 \\ \text { Substrate hexosamine released }(\%) & 36 & 26 & 59 & 89 & 88\end{array}$

\section{Stimulation of enzymic effect by metal ions}

The effect of each of the following metals on the lytic activity of Bacillus cereus spore enzyme was tested by adding them as sulphates to $B$. cereus cell walls ( $3 \mathrm{mg}$.) and enzyme from $12 \mathrm{mg}$. B. cereus spores (final concentration of metal ion, $10 \mu \mathrm{g} . / \mathrm{ml}.): \mathrm{Mn}^{++}, \mathrm{Fe}^{++}, \mathrm{Fe}^{+++}, \mathrm{Mg}^{++}, \mathrm{Co}^{++}$. The suspensions were 
incubated at $37^{\circ}$ for $18 \mathrm{hr}$. in parallel with suspensions without additions. The results given in Table 3 show that cobalt had a marked and manganese a moderate enhancing effect on the release of substrate hexosamine, but that ferrous or ferric iron and magnesium had no effect. The McIlvaine's buffer used in these experiments contained citric acid which is known to form nondissociated complexes with metals. To avoid such an effect, the experiment was repeated using $0.025 \mathrm{M}$ tris-(hydroxymethyl)-aminomethane $\mathrm{HCl}$ buffer (Gomori, 1946) and extended to investigate the effect of copper and nickel ions. The results (Table 4) showed that cobalt and manganese and to a lesser extent copper and nickel ions had a stimulating effect on hexosamine release.

\section{Table 3. Effect of metal ions on the lytic effect}

of Bacillus cereus spore enzyme

Buffer: 1:4 McIlvaine's ( $\mathrm{pH} 7 \cdot 4$ ); substrate: $3 \mathrm{mg}$. Bacillus cereus cell walls; lytic enzyme from $12 \mathrm{mg}$. B. cereus spores; metal ions: $10 \mu \mathrm{g} . / \mathrm{ml}$; incubation: $18 \mathrm{hr}$. at $37^{\circ}$; toluene added; duplicate tests.

$\begin{array}{lccccccc}\text { Metal ion addition } & \ldots & \text { Nil } & \mathrm{Mn}^{++} & \mathrm{Fe}^{++} & \mathrm{Fe}^{+++} & \mathrm{Mg}^{++} & \mathrm{Co}^{++} \\ \text {Substrate hexosamine released }(\%) & 63 & 70 & 61 & 66 & 64 & 92\end{array}$

Table 4. Effect of metal ions on the lytic effect of Bacillus cereus spore enzyme in the presence of an organic buffer

Buffer: 0.025 M-tris-(hydroxymethyl)-aminomethane $\mathrm{HCl}$; other details as in Table 3.

$\begin{array}{llcccccccc}\text { Metal ion addition } & \ldots & \mathrm{Nil} & \mathrm{Mn}^{++} & \mathrm{Fe}^{++} & \mathrm{Fe}^{+++} & \mathrm{Mg}^{++} & \mathrm{Co}^{++} & \mathrm{Cu}^{++} & \mathrm{Ni}^{++} \\ \text {Substrate hexosamine released (\%) } & \mathbf{2 8} & \mathbf{5 1} & \mathbf{2 1} & \mathbf{2 0} & \mathbf{2 6} & \mathbf{5 3} & \mathbf{3 8} & \mathbf{3 6}\end{array}$

\section{Inhibition and destruction of enzymic effect}

The effect of each of the following substances was tested in duplicate by adding them to cell walls (3 mg.) and enzyme from $12 \mathrm{mg}$. Bacillus cereus spores; KCN (mM, $10 \mathrm{~mm}$ ), chloroform (2 drops), NaF (25 mM), thiomersalate (1:5000), 8-hydroxyquinoline (oxine; $\mathrm{mm}$ ). The values given in brackets are final concentrations in a volume of $1 \mathrm{ml}$. The effect of heating the enzyme solution at $60^{\circ}$ for $1 \mathrm{hr}$. and at $100^{\circ}$ for $15 \mathrm{~min}$. was also investigated. The series was incubated at $37^{\circ}$ for $16 \mathrm{hr}$. with tests without additions and controls. Results of determinations of enzymic activity are given in Table 5, which shows that: (1) activity was destroyed by heat at $100^{\circ}$ for $15 \mathrm{~min}$. but not at $60^{\circ}$ for $1 \mathrm{hr}$.; (2) activity was inhibited by the presence of $10 \mathrm{mM}-\mathrm{KCN}$ but was unaffected by mM-KCN; (3) some inhibition occurred in the presence of mu-oxine.

\section{Optimum conditions for enzymic activity}

Rapidly visible lysis of walls of vegetative Bacillus cereus occurred when the walls were incubated at $58^{\circ}$ with buffered enzyme solution ( $\mathrm{pH} \mathbf{7 \cdot 4}$ ) containing cobalt $(10 \mu \mathrm{g} . / \mathrm{ml}$.). Enzyme from $12 \mathrm{mg}$. B. cereus spores released $75-85 \%$ of the hexosamine present in $3 \mathrm{mg}$. of cell walls in $2 \mathrm{hr}$. No hexosamine was released from heated cell walls incubated under these conditions in 
the absence of enzyme solution. The enzyme from $26,13,6 \cdot 5$ and $3 \cdot 25 \mathrm{mg}$. dry weight of spores released $77,70,35$ and $18 \%$, respectively, of the substrate hexosamine.

\section{The effect of lytic enzyme from various sources on different substrates}

The activity of an enzyme solution from Bacillus cereus spores was determined with vegetative cell walls of $\boldsymbol{B}$. cereus, $\boldsymbol{B}$. subtilis and $\boldsymbol{B}$. megaterium as substrates (Table 6). Spontaneous degradation of suspensions of $B$. subtilis walls was decreased but not stopped by heating them at $100^{\circ}$ for $15 \mathrm{~min}$. and this effect was taken into account in the results. Hexosamine-containing material was released by the enzyme in all cases.

Bacillus cereus spore enzyme solution also had a degradative effect on preparations of coats of $\boldsymbol{B}$. megaterium and of autoclaved $\boldsymbol{B}$. cereus spores (Table 6). The preparation of $\boldsymbol{B}$. megaterium spore coats used had been stored in a dried state for several months, and in contrast to the behaviour of freshly prepared spore coats, no spontaneous release of hexosamine-containing material occurred. Coats of viable $B$. cereus spores contained $2-3 \%$ hexosamine, and the release of hexosamine-containing material either spontaneously or in the presence of lysozyme was small (Strange \& Dark, 1956 b). It appeared that on disintegration of spores of $B$. cereus, the enzyme removed 'spore peptide' almost completely from the spore coat. It was found, however, that coats isolated from $B$. cereus spores autoclaved at $15 \mathrm{lb}$./sq.in. for $20 \mathrm{~min}$. contained $\mathbf{8 . 3} \%$ hexosamine. A significant amount of hexosamine-containing material was released from them by the enzyme solution.

Extracts from Bacillus anthracis spores had a similar activity to those from $B$. cereus spores. No activity was detected in extracts prepared from $B$. megaterium spores. With $\boldsymbol{B}$. megaterium it seemed likely that a similar enzyme must be present in the spore since it was previously shown that hexosaminecontaining material was released from freshly isolated spore coats suspended in buffer solution (Strange \& Dark, 1956 b). The enzymic activity of spore coat preparations of $B$. megaterium was therefore tested. Spore coats from $40 \mathrm{mg}$. of dried fresh spores were suspended in $1 \mathrm{ml}$. McIlvaine's buffer $(\mathrm{pH} \mathrm{7} 4$ ) and dispersed by shaking in the Mickle tissue disintegrator for $1 \mathrm{~min}$. The suspension $(0.25 \mathrm{ml}$.) was added to $3 \mathrm{mg}$. B. cereus vegetative cell walls suspended in $0.75 \mathrm{ml}$. water and after the addition of toluene, the mixture was incubated at $37^{\circ}$ for $16 \mathrm{hr}$. on a rotary shaker. After correcting for the hexosaminecontaining material released from the spore coats themselves, it was concluded that a small but definite release of material had occurred from $B$. cereus cell walls (Table 6).

\section{Partial purification of the crude lytic enzyme}

The crude enzyme preparation contained most of the spore nucleoprotein. Attempts to purify the enzyme by precipitation with ammonium sulphate were not successful since most of the material was precipitated at a low salt concentration. However, addition of clupein sulphate caused precipitation of a nucleoprotein complex and the filtrate, containing most of the enzymic 


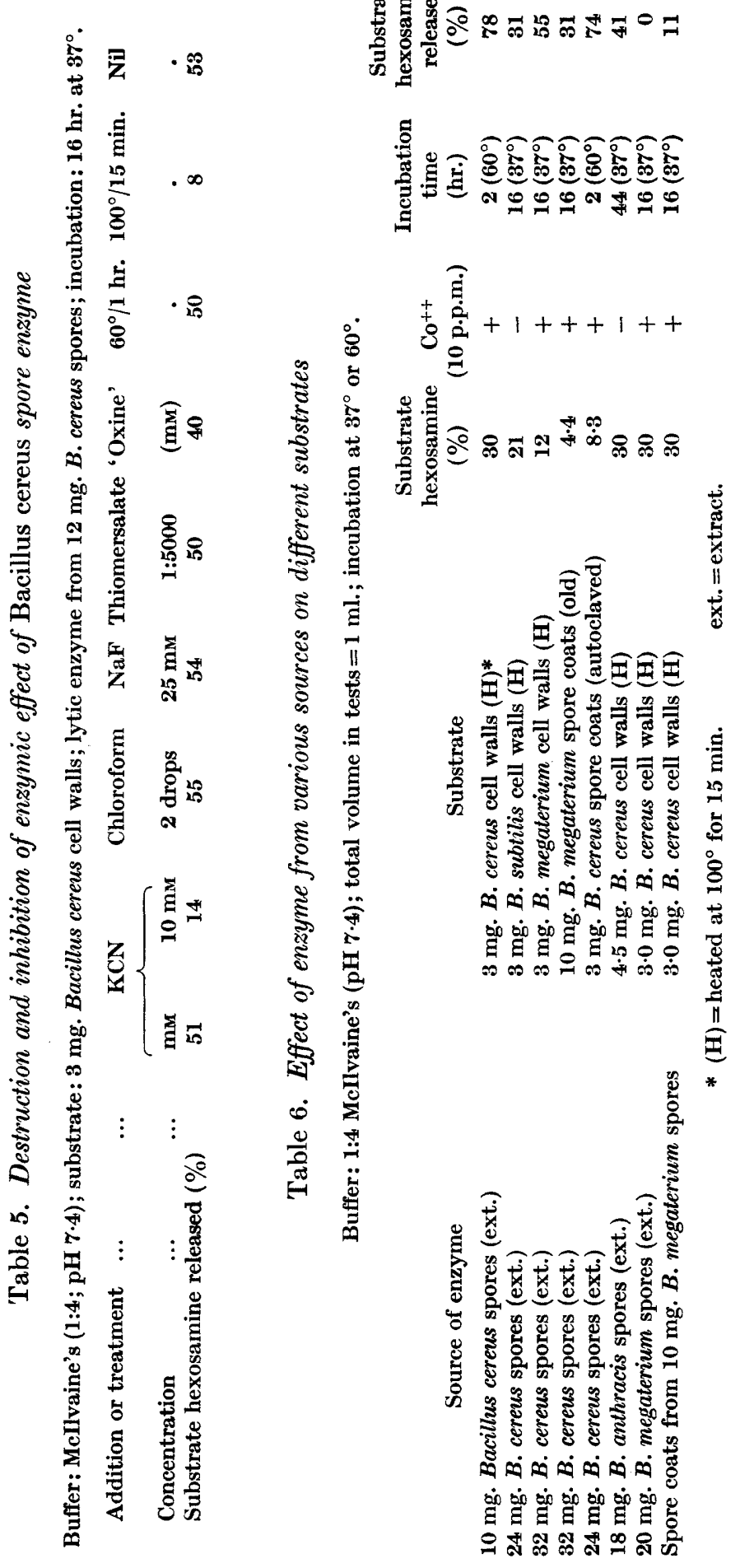


activity, could then be fractionated with ammonium sulphate. A solution (8.5 ml.; $\mathrm{pH} \mathrm{7.4)} \mathrm{containing} \mathrm{enzyme} \mathrm{from} 910 \mathrm{mg}$. dried spores was treated with $1.8 \mathrm{ml}$. of an aqueous solution of clupein sulphate $(1 \%, \mathrm{w} / \mathrm{v})$. The viscous nucleoprotein complex was centrifuged and rejected. The supernatant fluid $(9 \cdot 3 \mathrm{ml}$.) was treated with saturated ammonium sulphate solution $(3 \mathrm{ml}$.) and allowed to stand at $2^{\circ}$ for $2 \mathrm{hr}$. The precipitate (I) was collected by centrifugation. A second precipitate (II) formed when the supernatant fluid was treated with more ammonium sulphate solution $(6 \cdot 3 \mathrm{ml} . \equiv 0.5$ saturation) and left at $2^{\circ}$ for $16 \mathrm{hr}$. A third precipitate (III) formed on saturating the supernatant fluid from II with the solid salt. Each precipitate was dissolved in $9 \cdot 3 \mathrm{ml}$. of McIlvaine's buffer ( $\mathrm{pH} \mathrm{7.4)}$ ) and tested for enzymic activity. The release of hexosamine-containing material from $3 \mathrm{mg}$. Bacillus cereus cell walls by $0.25 \mathrm{ml}$. of solutions of I, II and III after incubation for $2 \mathrm{hr}$. at $60^{\circ}$ in the presence of cobalt (10 p.p.m.) was 20,86 and $38 \%$ respectively, of the total. After dialysis and freeze-drying solution II was found to contain $0.75 \mathrm{mg}$. dry wt. $/ \mathrm{ml}$. of material, indicating that $190 \mu \mathrm{g}$. was present in the enzymic test. The freeze-dried, dialysed preparation, on reconstitution in buffer, was not as active as the original solution, indicating that inactivation had occurred. No loss of activity occurred when buffered solutions of II were freeze-dried.

\section{The composition of the material released from vegetative cell walls}

Material for analysis was obtained by the action of enzyme from Bacillus cereus spores on vegetative cell walls of B. cereus, B. megaterium and B. subtilis. Details of the isolation procedure used are given in the following typical experiment. B. cereus cell walls $(80 \mathrm{mg}$.) were suspended in water $(6 \mathrm{ml}$.) and heated at $100^{\circ}$ for $15 \mathrm{~min}$. The suspension was centrifuged and the cell walls resuspended in McIlvaine's buffer ( $\mathrm{pH} 7 \cdot 4)$ dlluted 1:4 (8 ml.) containing enzyme from $200 \mathrm{mg}$. spores $+100 \mu \mathrm{g}$. cobalt. After incubation for $2 \mathrm{hr}$. at $58^{\circ}$ followed by $16 \mathrm{hr}$. at $37^{\circ}$ the undigested material was removed by centrifugation and the supernatant fluid cooled to $0^{\circ}$. Trichloroacetic acid solution $(25 \%, w / v)$ was added to a concentration of $3 \%(w / v)$ and the mixture allowed to stand $30 \mathrm{~min}$. at $0^{\circ}$. After removal of the precipitate by centrifugation, the supernatant fluid was neutralized with solid $\mathrm{NaHCO}_{3}$ and shaken with chloroform + amyl alcohol (Sevag, 1934) to remove remaining traces of protein. The protein-free solution was dialysed in the cold and freeze-dried. The yield of white solid was $40-45 \mathrm{mg}$. From $100 \mathrm{mg}$. of cell walls of $B$. megaterium or $B$. subtilis, 14-20 mg. of product was obtained. Material released from cell walls by the enzyme is subsequently referred to as peptide.

After acid hydrolysis followed by paper chromatography, the following constituents were found to predominate in all cases; DAP, glutamic acid, alanine, hexosamine, another amino sugar and glucose. The other amino sugar has been found in a number of bacterial walls (Cummins \& Harris, 1954, 1956) including those from Bacillus species (Salton, 1956) and appears to be identical with the one found in 'spore peptide' (Strange \& Powell, 1954; Strange \& Dark, 1956a). A possible structure, 3-O- $\alpha$-carboxyethylhexosamine has been 
suggested for it (Strange, 1956). Traces of other amino acids, principally glycine, serine and aspartic acid, were sometimes found. The analyses of the peptides given in Table 7 show that a large amount of hexosamine was present, varying from 37 to $47 \%$. Examination of $B$. megaterium cell-wall peptide by paper electrophoresis showed the presence of only one component staining with Naphthalene Black. The component moved rapidly towards the anode at

Table 7. Analysis of material released by lytic enzyme from cell walls of Bacillus cereus, B. megaterium and B. subtilis

\begin{tabular}{|c|c|c|c|c|}
\hline & $\begin{array}{c}\text { Total } \\
\text { nitrogen }\end{array}$ & $\begin{array}{c}\text { Hexosamine } \\
\text { (after } \\
\text { hydrolysis) }\end{array}$ & $\begin{array}{c}\text { Total } \\
\text { phosphorus }\end{array}$ & $\begin{array}{c}\text { Total } \\
\text { carbohydrate } \\
\text { as glucose }\end{array}$ \\
\hline & \multicolumn{4}{|c|}{ g. $/ 100 \mathrm{~g} \cdot$ cell-wall } \\
\hline Bacillus cereus & $6-7$ & $44-47$ & $0.3-0.4$ & $10-15$ \\
\hline B. megaterium & $\mathbf{5}$ & 37 & $0 \cdot 6$ & 7 \\
\hline B. subtilis & $6 \cdot 1$ & 37 & $1 \cdot 6$ & 10 \\
\hline
\end{tabular}

pH 8.6 and on elution from stained strips it was found to be similar in composition to the original peptide. On paper electrophoresis, $B$. cereus cell-wall peptide was found to contain several components moving towards the anode. Fractionation of an aqueous solution of the mixture with ethanol in the presence of barium acetate $(1 \%, w / v)$ gave a number of fractions, all of which contained the same constituents. The purest fraction obtained in $20 \%$ yield after repeated alcohol fractionations contained $6.5 \%$ nitrogen, $50 \%$ hexosamine (as glucosamine), $10 \%$ glucose, $0.27 \%$ phosphorus and $3.2 \%$ DAP. Paper electrophoresis of this fraction showed the presence of one major component moving towards the anode with a trace of a second, faster moving material. It appeared that the peptide material released by the lytic enzyme from $B$. cereus cell walls was a mixture of components with similar chemical composition but varying in the degree of polymerization. Glucose appeared to be part of the moiety and not present as a separate polysaccharide. No fraction free from phosphorus was obtained and the ultraviolet absorption spectrum of a solution of the fractionated material which contained $0.27 \%$ phosphorus, indicated that only a small amount of this constituent was present as nucleic acid.

Peptide from Bacillus megaterium cell walls gave no significant reaction for $N$-acetylhexosamine, but after incubation with lysozyme a positive reaction was obtained. Greater degradation occurred in the presence of an extract of the gut of Helix aspersa and the optimum $\mathrm{pH}$ value for activity was $5 \cdot 0$. In a typical experiment $10 \mathrm{mg}$. of material was treated with $0.3 \mathrm{ml}$. of a clarified extract ( $10 \mathrm{ml}$. aqueous extract from gut of twenty snails), $\mathbf{0 . 2} \mathrm{ml}$. McIlvaine's buffer (pH 5.0) and $0.7 \mathrm{ml}$. water. After incubation for $16 \mathrm{hr}$. at $37^{\circ}$ in parallel with controls $(a)$ without peptide, $(b)$ without snail enzymes, $N$-acetylhexosamine determinations were made on samples from the diluted centrifuged mixtures. Maximum colour, equivalent to $21 \% \mathrm{~N}$-acetylglucosamine, was obtained with Ehrlich's reagent after heating the test solution for $4 \mathrm{~min}$. with 
dilute alkali solution. $N$-acetylglucosamine also gave the maximum colour under these conditions, which suggested that the free $\mathrm{N}$-acetylated amino sugar had been released (Aminoff, Morgan \& Watkins, 1952). The reaction mixture was examined by paper chromatography and a spot was obtained which reacted with Ehrlich's reagent and had the same $R_{F^{\prime}}$ value as $N$-acetylglucosamine. No reaction for $\mathrm{N}$-acetylhexosamine was obtained with either control solution.

Under the above conditions very little $N$-acetylhexosamine-reacting material was released from Bacillus cereus cell-wall peptide by snail enzymes; lysozyme also had no effect. $N$-Acetylated amino sugars were present in this peptide since after hydrolysis with $\mathrm{N}$-acetic acid the products gave a positive Morgan \& Elson reaction and it appeared that the amino sugar linkages present differed from those in $B$. megaterium cell-wall peptide.

During these experiments it was found that snail enzyme lysed viable vegetative Bacillus subtilis at least as rapidly as lysozyme but had no effect on its spores.

\section{DISCUSSION}

Greenberg \& Halvorson (1955) reported the presence of an enzyme in culture filtrates of Bacillus cereus var. terminalis which lysed whole vegetative cells of this organism and of another strain of $B$.cereus. The enzyme was relatively heat stable and developed during the sporulation stage. Its activity was stimulated by the presence of manganese. These workers were unable to demonstrate enzymic activity in extracts of disintegrated cells and no evidence is given that the cell-wall was attacked. Nomura \& Hosoda (1956) prepared an enzyme from lysates of vegetative $B$. subtilis which lysed the isolated cell walls of this organism. In the present work the enzyme found in extracts from spore suspensions freed from vegetative forms attacked vegetative cell walls and spore coats. The criterion used for activity was the release of soluble nondialysable material which contained $\alpha \epsilon$-diaminopimelic acid, alanine, glutamic acid and amino sugars. These compounds predominate in cell walls from a variety of Gram-positive bacteria (Cummins \& Harris, 1954, 1956) including Bacillus species (Salton, $1953 a$ ). In the presence of sufficient enzyme, digestion of $B$. cereus vegetative cell walls was almost complete, whereas with $B$. megaterium cell walls a considerable amount of undigested material remained. In contrast to this Salton $(1953 b, 1956)$ showed that lysozyme had considerably less effect on the cell walls of $B$. cereus than on those of B. megaterium.

The material released by the enzyme of the present work had a characteristic composition similar to that of 'spore peptide'. It appears that this type of complex forms part of the integuments of both vegetative forms and spores of Gram-positive organisms. Compared with spore peptide from the same organism, the analogous cell-wall component contains more glucose, and it is probable that this is part of the amino acid + amino sugar moiety. The amount of phosphorus found in Bacillus megaterium 'spore peptide' was negligible $(0.03 \%)$, but significant amounts were found in all cell-wall peptides and 
purified fractions from them. In the present investigation it has not been possible to decide whether this is part of the peptide or a contaminant. Enzymes from snail gut are known to hydrolyse chitin and it is interesting to find that they splitsome of the cell-wall peptides. One of the enzymes present in snail gut preparations is $\beta$-glucosaminidase (Neuberger \& Pitt Rivers, 1939) and perhaps $\beta$-glucosaminide linkages are present in peptide from $\boldsymbol{B}$. megaterium cell walls but absent from the peptide of $B$. cereus cell walls or present to a much smaller extent. It has been found that $B$. megaterium 'spore peptide' is broken down to a much greater extent than that of $B$. cereus by snail enzymes.

The presence of the lytic enzyme in spores suggests a mechanism by which 'spore peptide' may be released from the spore coat on germination, especially as we have shown that the enzyme attacks coats of both Bacillus megaterium and autoclaved $\boldsymbol{B}$. cereus spores. It is possible that the relatively large amount of 'spore peptide' found in spore coats of $B$. megaterium is related to the small amount of lytic enzyme present in contrast to the small amount of peptide in the spore coats and larger amount of enzyme in spores of $\boldsymbol{B}$. cereus. Suspensions of cell walls prepared from sporulating cultures of $\boldsymbol{B}$. cereus lysed spontaneously on incubation, probably due to the presence in them of the same or a similar enzyme, the activity of which was destroyed on heating at $100^{\circ}$. The function of this type of system in the sporulating cell may be to lyse the sporangium, thus releasing the spore.

Several explanations can be offered to account for the decreasing amount of extractable enzyme present in Bacillus cereus spores during storage. It is possible that the enzyme is not in fact intracellular, but strongly adsorbed on the outer surface, where it is slowly denatured. It was, however, found that freshly harvested spores which had been washed sixteen times with reagents including sodium bicarbonate and acetic acid still gave active extracts. Spores after storage for one year at $2^{\circ}$ contained some extractable enzyme. It is possible that the freshly harvested spore contains an excess of the lytic enzyme and that only a relatively small proportion of this is incorporated or adsorbed on to the spore protoplasm, the remainder being slowly denatured and lost.

We are grateful to Mrs J. F. Powell for her interest in this work and for helpful suggestions.

\section{REFERENCES}

Aminoff, D., Morgan, W. T. J. \& Watkins, M. W. (1952). Studies in immunochemistry. II. The action of dilute alkali on the $N$-acetylhexosamines and the specific blood group mucoids. Biochem. J. 51, 379.

Chinard, F. P. (1952). Photometric estimation of proline and ornithine. J. biol. Chem. 199, 91.

Consden, R., Gondon, A. H. \& Martin, A. J. P. (1944). Qualitative analyses of proteins: a partition chromatographic method using paper. Biochem. J. 38, 224.

Cummins, C. S. \& Harris, H. (1954). Carbohydrate and amino acid constituents of cell walls of Corynebacterium diphtheriae. Biochem. J. 57, xxxii.

Cummins, C. S. \& Harris, H. (1956). The chemical composition of the cell wall in some Gram-positive bacteria and its possible value as a taxonomic character. J. gen. Microbiol. 14, 583. 
Elson, L. A. \& Morgan, W. T. J. (1933). A colorimetric method for the determination of glucosamine and chondrosamine. Biochem. J. 27, 1824.

Flynn, F. V. \& De Mayo, P. (1951). Micro-electrophoresis of protein on filter paper. Lancet, ii, 235.

Gladstone, G. P. \& Fildes, P. (1940). A simple culture medium for general use without meat extract or peptone. Brit. J. exp. Path. 21, 161.

Gomori, G. (1946). Buffers in the range of pH 6.5 to 9.6. Proc. Soc. exp. Biol., N.Y. $62,33$.

Greenberg, R. A. \& Halvorson, H. O. (1955). Studies on an autolytic substance produced by an aerobic sporeforming bacterium. J. Bact. 69,45 .

IMMERS, J. \& VASSEUR, E. (1950). Influence of sugars and amines on the colorimetric hexosamine method of Elson and Morgan and its possible elimination. Nature, Lond. 165, 898.

KIng, E. J. (1932). The colorimetric determination of phosphorus. Biochem. J. 26, 292.

MrckLe, H. (1948). Tissue disintegrator. J.R. micr. Soc. 68, 10.

Morgan, W. T. J. \& Elson, L. A. (1934). A colorimetric method for the determination of $N$-acetylglucosamine and $N$-acetylchondrosamine. Biochem. J. 28, 988.

Neuberger, A. \& Pitt Rivers, R. V. (1939). The hydrolysis of glucosaminides by an enzyme in Helix pomatia. Biochem. J. 33, 1580.

Nomura, M. \& Hosoda, J. (1956). Action of an autolytic enzyme of Bacillus subtilis on the cell wall. Nature, Lond. 177, 1037.

Partridge, S. M. (1948). Filter paper chromatography of sugars. I. General description and application to the qualitative analysis of sugars in apple juice, egg white and foetal blood of sheep. Biochem. J. 42, 238.

Partridge, S. M. (1949). Aniline hydrogen phthalate as a spraying reagent for chromatography of sugars. Nature, Lond. 164, 443.

Powell, J. F. (1953). Isolation of dipicolinic acid (pyridine-2:6-dicarboxylic acid) from spores of Bacillus megatherium. Biochem. J. 54, 210.

Poweli, J. F. \& Strange, R. E. (1953). Biochemical changes occurring during the germination of bacterial spores. Biochem. J. 54, 205.

Poweld, J. F. \& Strange, R. E. (1956). Biochemical changes occurring during sporulation in Bacillus species. Biochem. J. 63, 661 .

Robinow, C. F. (1951). Observations on the structure of Bacillus spores. J. gen. Microbiol. 5, 439.

Salton, M. R. J. (1953 $a$ ). Studies of the bacterial cell wall. IV. The composition of the cell walls of some Gram-positive and Gram-negative bacteria. Biochim. biophys. Acta, 10, 512.

Salton, M. R. J. (1953b). Cell structure and the enzymic lysis of bacteria. J. gen. Microbiol. 9, 512.

Salton, M. R. J. (1956). Bacterial cell walls; in 6th Symp. Soc. gen. Microbiol. p. 81. Cambridge University Press.

Salton, M. R. J. \& Horne, R. W. (1951). Studies of the bacterial cell wall. II. Methods of preparation and some properties of cell walls. Biochim. biophys. Acta, 7, 177.

Sevag, M. G. (1934). Eine neue physikalische Enteiweissungsmethode zur Darstellung biologisch wirksamer Substanzen. Biochem. Z. 273, 417.

Sørensen, M. \& Haugaard, G. (1933). Über die Anwendbarkeit der Orcinreaktion zur Bestimmung der Art und Menge von Kohlenhydratgruppen in Eiweisstoffen. Biochem. Z, 260, 247.

Sterne, M. (1937). Variation in Bacillus anthracis. Onderstepoort J. vet. Sci. 8, 271.

Strange, R. E. (1956). The structure of an amino sugar present in certain spores and bacterial cell walls. Biochem. J. 64, $23 \mathrm{P}$.

Strange, R. E. \& Dark, F. A. (1956a). An unidentified amino-sugar present in cell walls and spores of various bacteria. Nature, Lond. 177, 186. 
Strange, R. E. \& Dark, F. A. (1956b). The composition of the spore coats of Bacillus megatherium, B. subtilis and B. cereus. Biochem. J. $62,459$.

Strange, R. E. \& Dark, F. A. (1956c). A comparison of the composition of and the effect of enzymes on spore peptide and a hexosamine complex in vegetative cell walls of Bacillus subtilis, B. megatherium and B. cereus. J. gen. Microbiol. 15, xii.

Strange, R. E. \& Powell, J. F. (1954). Hexosamine-containing peptides in spores of Bacillus subtilis, B. megatherium and B. cereus. Biochem. J. 58, 80.

(Received 10 September 1956) 